Received 21.03.2017 Reviewed 11.06.2017 Accepted 05.07.2017

A - study design

B - data collection

C - statistical analysis

D - data interpretation

E - manuscript preparation

F - literature search

\section{Spatio-temporal changes in water quality in an eutrophic lake with artificial aeration}

\author{
Anabella FERRAL ${ }^{1)}$ ABCDEF , Velia SOLIS ${ }^{2) ~ A C D E F}$, Alejandro FRERY ${ }^{3)}$ ACDEF, \\ Alejandro ORUETA ${ }^{4)}$ ABD , Ines BERNASCONI) ABD, \\ Javier BRESCIANO ${ }^{4)}$ ACD , Carlos M. SCAVUZZO' ${ }^{1)}$ ACDE $\bowtie$
}

\footnotetext{
1) National University of Córdoba and CONAE, Institute of Higher Space Studies Mario Gulich, Ruta C45, km 8, Falda del Carmen, 5587, Córdoba, Argentina; e-mail: scavuzzo@conae.gov.ar, aferral@conae.gov.ar

2) Physical Chemistry Department, Faculty of Chemical Sciences, INFICQ-CONICET, Haya de la Torre esq. Medina Allende, CP 5000, Córdoba, Argentina; e-mail: veliamatilde@gmail.com

${ }^{3)}$ Federal University of Alagoas, Laboratory of Scientific Computation and Numerical Analysis, Av. Lourival Melo Mota s/n. Maceio 57072-900 AL, Brazil; e-mail: acfrery@gmail.com

4) Water Resources Secretary of Córdoba Province, Hydrology Department, Humerto Primo 607, CP 5000, Córdoba, Argentina; e-mail: aorueta@gmail.com, iabernasconi@gmail.com,Jbresiano@gmail.com
}

For citation: Ferral A., Solis V., Frery A., Orueta A., Bernasconi I., Bresciano J., Scavuzzo C.M. 2017. Spatio-temporal changes in water quality in an eutrophic lake with artificial aeration. Journal of Water and Land Development. No. 35 p. 27-40. DOI: 10.1515/jwld-2017-0065.

\begin{abstract}
In this work we present novel results concerning water quality changes in an eutrophic water body connected with an artificial aeration system installed in it. Sixty one in-situ and laboratory measurements of biogeochemical variables were recorded monthly between October 2008 and June 2011 to evaluate temporal and spatial changes in San Roque reservoir (Argentina). $t$-Student mean difference tests, carried out over the whole period, showed with $95 \%$ confidence that a monitoring point located at the centre of the water body is representative of the chemical behaviour of the reservoir. Thermal stratification was observed in all sampling sites in the summer, but the frequency of these episodes was markedly lower in bubbling zones. Mean chlorophyll-a concentrations were $58.9 \mu \mathrm{g} \cdot \mathrm{dm}^{-3}$ and $117.0 \mu \mathrm{g} \cdot \mathrm{dm}^{-3}$ in the absence and in the presence of thermocline respectively. According to the $t$-Student test, this difference was significant, with $p<0.001$. Phosphate release from sediments was corroborated under hypoxia conditions. ANOVA one way analysis did not show significant spatial differences for any variable. Mean normalize spatial index (MENSI) was developed to compare data from different regions affected by high temporal variability. It proved to be useful to quantify spatial differences. Structure analysis of temporal series was used to scrutinize both chemical and spatial association successfully. Three chemically different zones were determined in the reservoir. This study demonstrated that spatial comparisons by means of marginal statistics may not be an adequate method when high temporal variation is present. In such a case, temporal structure analysis has to be considered.
\end{abstract}

Key words: eutrophication, phosphates, projection techniques, statistical analysis, thermal stratification, time series, water quality 


\section{INTRODUCTION}

Degradation of continental water quality is a worldwide problem which has been going worse during the last decades and has been affecting the ecosystem and population's health [MOORE et al. 2008]. Moreover, reliability of the public water system has been decreasing due to bad odour and taste episodes, as Parinet has pointed out recently for $\mathrm{Ca}$ nadian citizens [PARINET et al. 2010]. The problems mentioned above are related to eutrophication processes, mainly in warm seasons. An important consequence of algae blooms is the hazard of toxic release. Furthermore, it has recently been demonstrated that species diversity of fish evolved in response to ecological opportunity, and that eutrophication, by diminishing this opportunity, has driven extinctions through speciation reversal and demographic decline [VONLANTHEN et al. 2012]. In this framework, control of water quality in reservoirs is of primary importance. The San Roque Lake is the most important water source for the city of Córdoba, whose population is around 1.4 million. Appreciable concentrations of Microcystins, an algae-derived toxic compound, were present not only in water but also in fish from this reservoir [AMÉ et al. 2003; RUIZ et al. 2013]. Regarding the water column regime, this lake can be considered monomictic, with a convective mixing during autumn and winter and thermal stratification in spring and summer [ANTENUCCI et al. 2003]. During thermal stratification two water layers with different temperatures coexist separated by a well-defined thermocline. At this stage, anoxia episodes in hipolimnion become important. In anoxic environments the metabolic pathways of anaerobic bacteria consume iron and manganese hydroxides as oxidants, turning them to iron (II) and manganese (II) soluble species [LOVLEY, PHILLIPS 1988]. Consequently, high amounts of phosphate species which were adsorbed on sediments, rich in this kind of hydroxides, are released to water column [MORTIMER 1942]. Under these circumstances, in addition to light and warm temperature, algae find no limit to growth [NICKLISCH et al. 2008; PAERL, PAUL 2012]. Solutions of eutrophication problem should be both preventive and corrective [GROMIEC, GROMIEC 2010]. The techniques used for the restoration of lakes or to prevent eutrophication are numerous (chemical, biologic, mechanical, etc). Many attempts are made by managing external sources of nutrients as rivers and runoff loads [HAMILTON et al. 2016; STEIMANN et al. 2015]. Ajeagah and coworkers have recently performed water assessment of a hypereutrophic tropical water system and run the Water Quality Analysis Simulation Program (WASP) of the United State Environmental Protection Agency (USEPA) to evaluate remediation capacity [AJEAGAH et al. 2017]. They concluded that wet dredging is a valid alternative to extract nutrient rich water from depth. There are also methods to manage internal phosphate release from sediments which use (P)-ad- sorbent materials, but it remains a challenge to develop ecologically benign and cost-effective technology [Douglas et al. 2016]. In this sense the process of artificial aeration is an interesting method to prevent phosphate release from sediments. However, few analysis related to the effects of this technology on water quality can be found in scientific literature and ambiguous conclusion are observed. Whereas some reports are sceptical of its benefits, others have obtained promising results. Lawson and Anderson performed a three-year study on water quality before and after artificial aeration of Lake Elsinore, California [LAWson, ANDERSON 2007]. Acoustic Doppler Current Profiler (ADCP) measurements showed that mixing energy was not being efficiently transmitted laterally into the water column, and that both stratification and a large area of anoxic sediments persisted despite pump operation during summers. GÄCHTER and WEHRLI [1998] performed a ten-year study on artificial aeration mixing and oxygenation of two eutrophic lakes but they were not able to detect effects on the internal phosphorous loading. On the other hand, recent studies showed that Cylindrospermopsis concentration (a toxic cyanobacterial species) was lower in an artificial non-stratified off-stream storage dam as compared with the riverine sites [STITZ et al. 2013]. Moreover, artificial mixing in the hypertrophic Lake Nieuwe Meer, located in the Netherlands, was successful in preventing blooms of the cyanobacteria Microcystis [VISSER et al. 1997]. Numerical models carried out to evaluate bubbling effects on a reservoir indicated that improvement of water quality can be obtained by using the suitable gas flow rate and number of bubble ports, and applying it at an appropriate period of the year [IMTEAZ, ASAEDA 2000].

In October 2008 a diffuser system was set up, by Córdoba Water Management authorities, in the eastern area of San Roque reservoir in order to mitigate the eutrophication process. The theoretical framework for the design adopted was set by Antenucci and collaborators after several chemical and hydrologic studies [ANTENUCCI et al. 2003]. The purpose of the system was to break thermal stratification so as to increase oxygen level at the bottom of the lake and prevent phosphate release. At the same time, it is well known that turbulent surface waters hinder the development of Cyanophites. In view of previous results, it was necessary to evaluate the suitability of the artificial aeration devices being employed in the San Roque reservoir. For that purpose a full spatial and temporal monitoring plan was carried out.

Monthly measurements of sixty-one physicochemical, biological, and microbiological variables were performed in strategic sites of the lake during three years. These variables were assessed both quantitatively and qualitatively, yielding a wealth of new information. For the first time, marginal statistical and structure analysis of temporal series were simultaneously carried out and then compared in order to find spatial patterns. This study constitutes a new method 
for assessing the efficiency of artificial aeration concerning algae growth and other factors related to water quality.

This paper unfolds as follows. Section "Materials and methods" presents the study area, artificial aeration system, field measurement details, and data analysis methods. Section "Results and discussion" shows the results obtained with different numerical approaches and discusses them in the frame of previous knowledge and new findings. Finally, section "Conclusions" concludes the article by presenting bulleted points which state artificial aeration effects on water quality and interpretation of spatio-temporal changes as well as its dependence on the mathematical tools used.

\section{MATERIALS AND METHODS}

\section{STUDY AREA}

Figure 1 shows a map of the San Roque reservoir and its four tributaries, the rivers San Antonio, Cosquín, Los Chorrillos and Las Mojarras. It is locat-

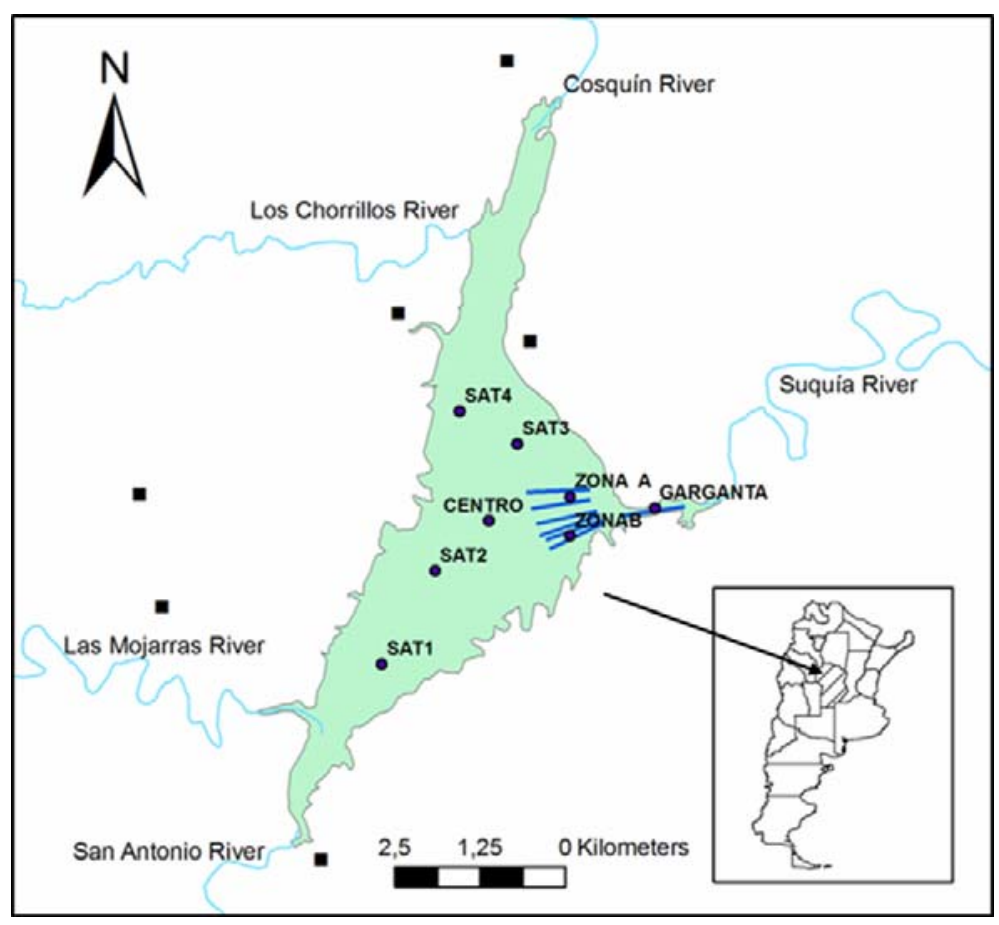

Fig. 1. Map of San Roque reservoir showing the location of screening samples in circles, diffusers lines in black, main neighbour cities in squares, tributaries and outfall. Inset map presents Argentina with Córdoba province in stripped pattern; source: own elaboration ed $600 \mathrm{~m}$ a.s.l. in the Punilla Valley, a semiarid region of Córdoba province, Argentina. It has a drainage area of $1750 \mathrm{~km}^{2}$, a surface of $15.01 \mathrm{~km}^{2}$, an approximated volume of $200 \mathrm{hm}^{3}$ and a mean depth of $13 \mathrm{~m}$. Water residence time ranges from one to eight months. It was the world's largest dam at the time of its construction (1888) and the first one built in Argentina. In 1944 it was enlarged to increase its reservoir capacity. Its outfall is the Suquía River, which crosses the city of Córdoba some kilometres downstream. Figure 1 also shows in blue the line diffusers.

\section{MONITORING ASSESSMENT}

Monitoring assessment was organized according to US-EPA (United States Environmental Protection Agency) guidelines for lakes undergoing a restoration process.

Variables: Table 1 shows sixty one biogeochemical variables measured from October 2008 to June 2011 by the Secretary of Water Resources and Coordination of the province of Córdoba (Sp. Secretaría de Recursos Hídricos y Coordinación de la provincial de Córdoba). Dissolved oxygen, conductivity and $\mathrm{pH}$ were measured in situ so as gen, conductivity and $\mathrm{pH}$ were measured in situ so as to obtain the corresponding vertical profiles in real time, as well as the water temperature profile, necessary to study thermal stratification and its relation with eutrophication. In situ measurements were performed every fifteen days at the beginning, and monthly since January 2010, whereas laboratory measurements were carried out monthly. A total of 50 monitoring dates were established for variables measured in situ and 28 for those measured at laboratory.

Figure 1 shows the eight monitoring sites selected in order to evaluate diffuser performance. As it can be seen, three points were located over diffuser operation lines (Zone A, Zone B and Garganta), one was chosen as a control point at the centre of the lake (Centre) while the other four were distributed between the southern (SAT 1 and SAT 2) and northern (SAT 3 and SAT 4) area. A Garmin GPS model eTrex Vista $\mathrm{HCx}$ was used to reach monitoring points with an accuracy of $15 \mathrm{~m}$ or less.

Sampling, storage, preservation, and analysis of water samples were carried out according to the methodology proposed by the Standard Methods for Water and Wastewater [EATON et al. 2005]. Table 1 lists the methods employed. In situ measurements as $\mathrm{pH}$, dissolved oxygen, water temperature and conductivity were registered with a Horiba U-22 multiparametric probe.

\section{DATA ANALYSIS}

Temporal, spatial, physicochemical, biological, and microbiological variables were introduced in a "data frame" in $\mathrm{R}$ environment by means of data mining approaches [R Development... 2013]. Columns and rows correspond to variables (or variable functions) and particular cases respectively. The working database had 100 columns and 4800 rows; the resulting data frame, then, had 480000 cells to be 
Table 1. Variables measured by SRHyC (Sp. Secretaría de Recursos Hídricos y Coordinación de la provincial de Córdoba) during the period October 2008-June 2011

\begin{tabular}{|c|c|c|}
\hline Variable & Determination method & Type of measurement \\
\hline Temperature & SMWW-Met-2550 Temperature B & in situ- profile \\
\hline $\mathrm{pH}$ & SMWW-Met-4500- $\mathrm{H}^{+} \mathrm{B}$ & in situ-profile \\
\hline Dissolved oxygen & SMWW-Met-4500-O G & in situ-profile \\
\hline Conductivity & SMWW-Met-2510 B & in situ-profile \\
\hline Solar Radiation & Pyranometer (Data supplied by INA, Instituto Nacional del Agua) & hourly \\
\hline Chlorophyll-a & SMWW-Met 10200 H.2.b. & surface \\
\hline Total phosphorus & SMWW-Met 4500- P B\&E & surface and bottom \\
\hline Secchi disk deph & SMWW-Met 2130-B & - \\
\hline $\mathrm{Na}^{+}$ & SMWW-Met 2130-Na B & surface \\
\hline $\mathrm{Ca}^{+}$ & SMWW-Met 3500-Ca D & surface \\
\hline $\mathrm{NO}_{3}^{-}$ & SMWW-Met $4500-\mathrm{NO}_{3}{ }^{-} \mathrm{E}$ & surface \\
\hline PRS & SMWW-Met 4500-P E & surface and bottom \\
\hline $\mathrm{K}^{+}$ & SMWW-Met 2130-K B & surface \\
\hline $\mathrm{F}^{-}$ & SMWW-Met 4500-F B\&D & surface \\
\hline $\mathrm{Mn}^{2+}$ & SMWW-Met 3500-Mn B & bottom \\
\hline $\mathrm{Fe}^{2+}$ & SMWW-Met 3500-Fe B & bottom \\
\hline $\mathrm{SO}_{4}{ }^{2-}$ & SMWW-Met $4500-\mathrm{SO}_{4}{ }^{2-} \mathrm{D}$ & surface \\
\hline Cyanophytes & $\begin{array}{l}\text { SMWW-Met } 10200 \mathrm{~F}: \text { Anabaena sp., Microcystis sp., Pseudoanabaena sp., Oscillatoria sp, } \\
\text { Aphanocapsa sp., Planktothrix sp. }\end{array}$ & surface \\
\hline Chrysophytes & $\begin{array}{l}\text { SMWW-Met } 10200 \text { F: Cyclotella sp., Stephanodiscus sp., Aulacoseira sp., Melosira sp., } \\
\text { Navicula sp., Nitzschia sp., Diatoma sp., Cocconeis sp., Hantzschia sp., Gomphonema sp., } \\
\text { Mallomonas sp., Biddulphia sp., Cymbella sp., Fortiella sp., Cymatopleura sp., Surirella sp. }\end{array}$ & surface \\
\hline Chlorophytes & $\begin{array}{l}\text { SMWW-Met } 10200 \text { F: Cyclotella sp., Stephanodiscus sp., Aulacoseira sp., Melosira sp., } \\
\text { Navicula sp., Nitzschia sp., Diatoma sp., Cocconeis sp., Hantzschia sp., Gomphonema sp., } \\
\text { Mallomonas sp., Biddulphia sp., Cymbella sp., Fortiella sp., Cymatopleura sp., Surirella sp. }\end{array}$ & surface \\
\hline Pyrrophytes & SMWW-Met 10200 F: Chroomonas sp., Cryptomonas sp., Ceratium sp., Peridinium sp. & surface \\
\hline Euglenophytes & SMWW-Met $10200 \mathrm{~F}$ : Euglena sp., Trachelomonas sp. & surface \\
\hline
\end{tabular}

Explanations: SMWW correspond to standardized methods (APHA 2005).

Source: own study.

analysed. The amount of information to process was huge, since eight sites and almost twenty different depths were registered for each monitoring date. However, not all variables were measured at every water depth. In those cases the corresponding cell shows a $N A$ (not analysed) indication. One of the key tools for this work was R software, which was employed, not only to extract and analyse data of interest but also to develop routines and to perform automatic procedures. Carlson Index (TSI) was used to quantify eutrophication [CARLSON 1977]. TSI is a logarithmic function of transparency (in terms of the Secchi disk depth), total phosphorous or chlorophyll-a concentration. In this work TSI was calculated according to the equation (1) and expressed in $\mu \mathrm{g} \cdot \mathrm{dm}^{-3}$. It ranges from 0 to 110 and higher values of TSI indicate a bigger amount of algae. A water body can be classified as hypertrophic, eutrophic, mesotrophic, oligotrophic or ultraoligotrophic as a function of TSI values (Tab. 2).

$$
T S I=30.6+9.81 \ln (\text { chlorophyll-a) }
$$

Table 2. Lake's classification as a function of its productivity according to Carlson index

\begin{tabular}{|c|c|}
\hline$T S I, \mu \mathrm{g} \cdot \mathrm{dm}^{-3}$ & Trophic level \\
\hline $0-20$ & ultraoligotrophic \\
\hline$>20-40$ & oligotrophic \\
\hline$>40-50$ & mesotrophic \\
\hline$>50-70$ & eutrophic \\
\hline$>70$ & hypereutrophic \\
\hline \multicolumn{2}{|c|}{$T S I=30.6+9.81 \ln$ (chlorophyll-a) } \\
\hline
\end{tabular}

Source: own elaboration acc. to CARLSON [1976].
Mean normalize spatial index (MENSI). This index was developed to compare chemical variables from different spatial origin but affected by a common high temporal dispersion. The hypothesis behind this index was that high temporal changes do not allow quantification of spatial changes. MENSI is calculated through equation (2):

$$
M E N S I=\frac{\sum_{j=1}^{M}\left(\frac{n_{i}}{\sum_{i=1}^{N} n_{i} / N}\right)_{j}}{M}
$$

where: $j=$ indexes the date, $i=$ the monitoring sites, $M=$ the total monitoring dates, $N=$ the total monitoring sites, $n=$ stands for the value of the variable, i.e. chlorophyll-a concentration.

If the behaviour of a monitoring site is similar to that of lake average on each measurement date, then MENSI value will approach one. If that site presents higher values on each date, MENSI will be higher than one; otherwise, the index value will be lower than one.

Marginal statistics. Descriptive statistics were performed using the $\mathrm{R}$ "stats" package included in the platform. The $t$-Student mean difference test was used to compare average values of different variable distributions. Distribution normality and variance homocedasticity were assessed by the Kolmogorov-Smirnof and Levene tests respectively. One way ANOVA 
(Analysis of Variance) was employed to evaluate spatial differences for the main biogeochemical variables. In order to make temporal and spatial variations evident, box plots were used. When two boxes notches do not overlap this is a strong evidence for the different character of their medians.

Bivariate analysis. Correlograms performed with R software within the frame of the "Corrgram" package were used to evaluate and visualize Pearson correlation coefficients between variables [FRIENDLY 2002].

Projection analysis. Temporal Pex software was used to evaluate the presence of patterns in biogeochemical temporal series. This tool allows reducing the dimensionality of each vector (series length) by an iterative algorithm which preserves a distance relation between the series involved. Finally, a two dimensional graph was obtained where each point is a projection of a time series. Closed points in space indicate high similarities between series patterns. In this work, a monthly time step was considered for each series of twenty eight elements. Interactive Document Map projection technique (IDMAP) was applied to reduce dimension of time series and Euclidean distances were used to measure differences. As this distance can only address time series of the same size, missing data were replaced by linearly interpolated values. After this procedure, a set of 28-month series was obtained. A projection map was built to visualize each temporal series as a point. Details on mathematical concepts used by this approach can be found in [ALENCAR et al. 2008] and references therein.

\section{RESULTS AND DISCUSSION}

\section{MARGINAL STATISTICAL ANALYSIS}

Figure 2 depicts the time dependence of temperature, chlorophyll-a, total phosphates, Secchi disk depth, total algae, $\mathrm{pH}$, conductivity, suspended solids, and surface dissolved oxygen, which were measured from October 2008 to June 2011.

As expected, water temperature data (which are primarily determined by physical factors such as incident sunlight) changed periodically, presenting maxima and minima in summer and winter respectively. In the case of conductivity values, their positive dependence on temperature was evident, as well as its increase in 2009, a dry year compared with rainy 2008 and 2011, in agreement with the negative dependence of conductivity on water dilution. The rest of the variables followed the same periodicity as temperature did, although with a greater scatter of numerical values. This can be attributed to the presence of biotic factors, mainly the amount of microorganisms whose metabolism usually influences both physical and chemical water parameters. Due to its limnological characteristics, Centre sampling point was expected to be representative of the averaged chemical behaviour of the other eight monitoring sites yearly considered. Statistical comparisons were therefore made between each variable averaged over all measurement sites and the values coming from Centre site only. Data from all sampling dates were included. The statistical analysis considered significant $p$ values of
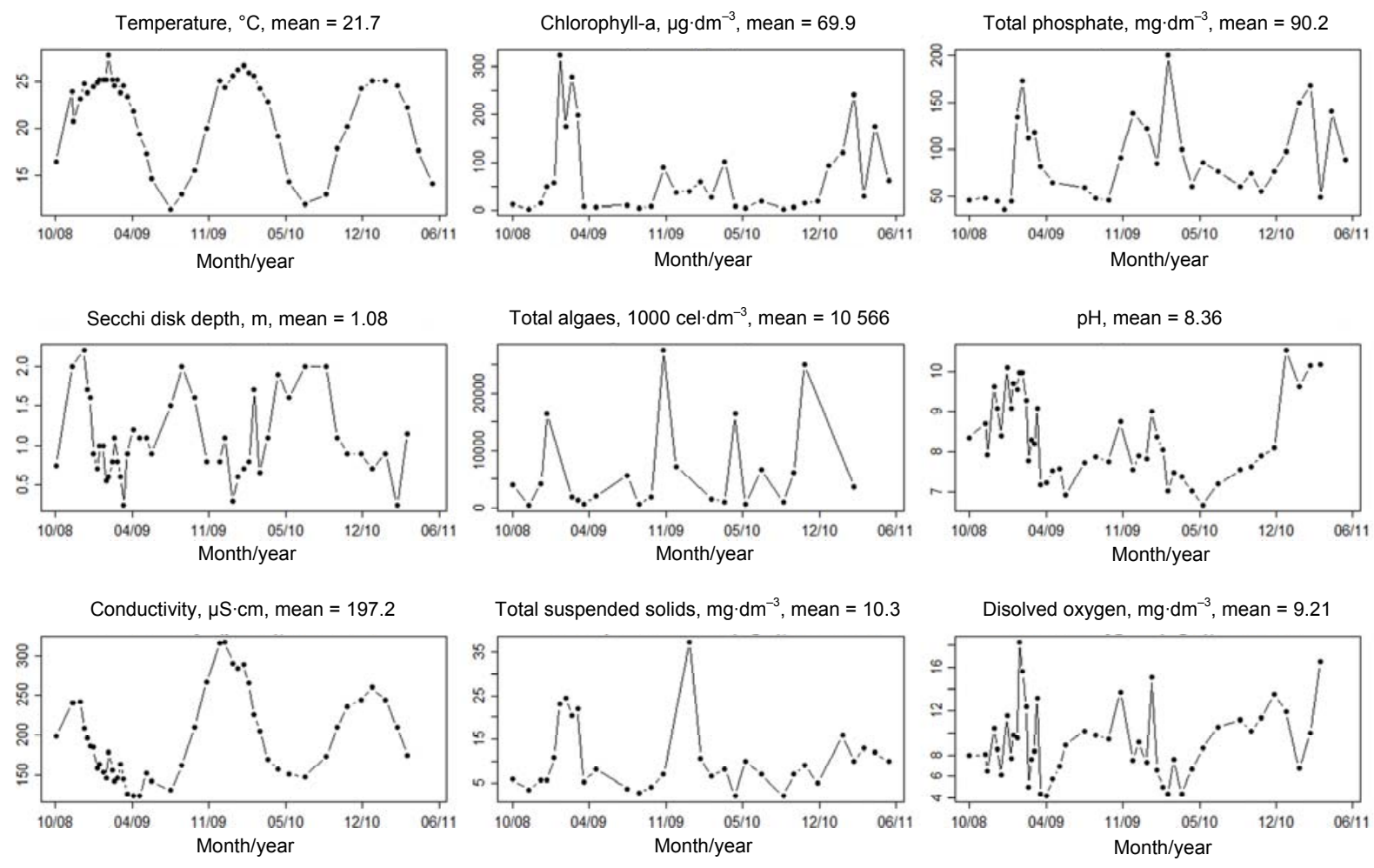

Fig. 2. Temporal series of most important surface variables for Centre station; mean value is highlighted at the top of each graph, horizontal axes represent time in month/year format; source: own study 
the mean differences for $t$-Student test. This requires the fulfillment of three conditions: independence of variables, normal distribution of each data set, and normal distribution variances or homoscedasticity. These conditions are not always met in real systems. However, an analysis for the logarithm of chlorophyll-a using the Kolmogorov-Smirnov and Levene tests showed that both data from the eight sampling stations and from the Centre point were normal and homoscedastic.

In the $t$-Student test, $p$ values below 0.05 indicate that the corresponding mean values are different with a confidence level of 95 percent while higher values indicate that they can be considered as indistinguishable. Our results showed $p$ values far above the 0.05 threshold. For instance, conductivity, TDS, $\mathrm{Na}^{+}, \mathrm{Ca}^{2+}$ and nitrates gave $p$ values above 0.93 , whereas temperature, $\mathrm{O}_{2}$ (dis), $\mathrm{pH}$, soluble phosphates, total phosphates, chlorophyll-a, $\mathrm{K}^{+} \cdot \mathrm{F}^{-}$and sulphates gave $p$ values ranging between 0.42 and 0.88 . It must be noted that values for total algae yielded a lower significant $p=0.10$, but clearly above the limit of 0.05 .

On the basis of the significant $p$ values obtained, we can be sure that the analysed monitoring variables corresponding to the central monitoring site are representative of the reservoir as a whole. In this sense, mean concentration of chlorophyll-a measured at that point can be used to define the trophic state of the reservoir. The Carlson index calculated according to equation (1) and mean chlorophyll-a concentration, presented in Figure 2, is equal to 64.1. This value is comparable to the one reported for this lake by other authors, i.e. 62.4, indicating that this water body can be classified as eutrophic according to Table 2 [AMÉ et al. 2003].

\section{BIVARIATE ANALYSIS}

Exploratory visual display is advisable to represent patterns of relations among variables when their number is moderately large. Correlograms render the value of Pearson's correlation coefficients to depict their signs and magnitudes graphically. Similar variables are arranged adjacently for the sake of better perception; positive and negative correlations are visualized in blue and in red respectively. Figure 3 shows a correlogram graph performed for chemical data measured at surface and bottom waters of the reservoir during field campaigns.

Variables were chosen according to their incidence in algae growth and phosphorous release mechanism. Dissolved oxygen $\left(\mathrm{O}_{2}\right), \mathrm{pH}$, chlorophyll-a logarithm (lnchlo), suspended solids (SS), total phosphorous (TP), soluble reactive phosphorous (RSP), total coliforms (Tcolf), Secchi disk depth $(S D D)$, and nitrates $\left(\mathrm{NO}_{3}\right)$ were considered for surface data while manganese (II) (Mn), iron (II) (Fe), soluble reactive phosphorous (RSPf), and dissolved oxygen $\left(\mathrm{O}_{2} \mathrm{f}\right)$ were analysed for deep water data. The order of displayed variables came from a principal component analysis [FRIENDLY 2002]. Only significant correlations with

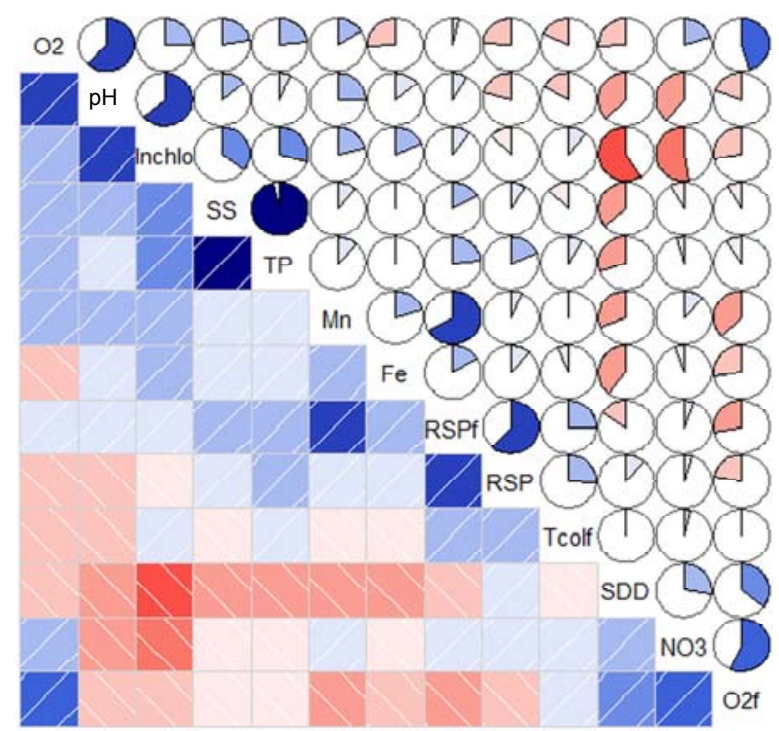

Fig. 3. Representation of Pearson's correlations between main chemical variables in a correlogram graph. Blue and red indicate negative and positive correlation respectively, while the colored piece of each circle represents the amount of it; variables involved are: $\mathrm{O}_{2}=$ dissolved oxygen, $\mathrm{pH}$, lnchlo = logarithm of chlorophyll-a, $S S=$ suspended solids, $\mathrm{TP}=$ total phosphorus, $\mathrm{Mn}=$ manganese II from bottom,

$\mathrm{Fe}=$ iron II from bottom, $\mathrm{RSPf}=$ reactive dissolved phosphorous from bottom, RSP $=$ reactive dissolved phosphorous, Totcolf $=$ total coliforms, $S D D=$ Secchi disk depth, $\mathrm{NO}_{3}=$ nitrates, $\mathrm{O}_{2} \mathrm{f}=$ dissolved oxygen from bottom; source: own study

90 per cent confidence will be discussed. For surface variables, the logarithm of chlorophyll-a concentration presents a positive correlation with $\mathrm{pH}$, dissolved oxygen, suspended solids and total phosphorous whereas negative correlations are observed for nitrates and SDD (transparency). This behaviour could be explained by the chemical equation presented below to describe photosynthesis (right direction) and respiration (reversal direction) in aquatic systems based on Redfield relationships [STUMM, MORGAN 2012]. It can be observed that carbon dioxide, nitrates, and reactive phosphorous are consumed while oxygen and assimilated total phosphorous are produced.

$$
\begin{aligned}
& 106 \mathrm{CO}_{2}+16 \mathrm{NO}_{3}{ }^{-}+\mathrm{HPO}_{4}{ }^{2-}+122 \mathrm{H}_{2} \mathrm{O}+18 \mathrm{H}^{+}+ \\
& +(\text {trace elements and light }) \rightarrow \\
& \rightarrow\left[\left(\mathrm{CH}_{2} \mathrm{O}\right)_{106}\left(\mathrm{NH}_{3}\right)_{16} \mathrm{H}_{3} \mathrm{PO}_{4}\right]+138 \mathrm{O}_{2}
\end{aligned}
$$

For bottom variables, the logarithm of chlorophyll-a concentration presented a positive correlation with iron (II) and manganese (II) while a negative correlation was observed for dissolved oxygen. In addition, the strong positive correlation observed between bottom and surface reactive soluble phosphorus indicated that sediments are an important source of this nutrient. This behaviour was expected during thermal stratification and it will be discussed in terms of anoxia episodes in the next section.

Analogous analysis was performed to correlate logarithm concentration of chlorophyll-a with physical and biological variables. Significant positive cor- 
relations were observed for temperature (0.62), conductivity (0.27), and solar radiation (0.18). Respect to biological variables, total algae as well as cyanophytes, chlorophytes, pirrophytes, euglenophytes and crysophytes abundance were considered. Total algae showed significant positive correlation (0.48) with logarithm of chlorophyll-a. Cyanophytes was the group which presented the highest value $(0.47)$, followed by chlorophytes $(0.25)$ and pirrophytes $(0.12)$. Cyanophytes and total algae presented a coefficient of correlation equal to 0.98 , indicating that algae blooms are mostly governed by this species. A huge amount of biological information was acquired during field campaigns but further analysis is beyond the scope of this paper and it will be discussed in a future work.

\section{EVIDENCES OF INTERNAL PHOSPHATE SOURCE'S MECHANISM}

Bivariate analysis provided evidence for phosphorus release from sediments. Figure 4 presents normalized temporal curves of variables measured in deep waters which are involved in the phosphorous release process.
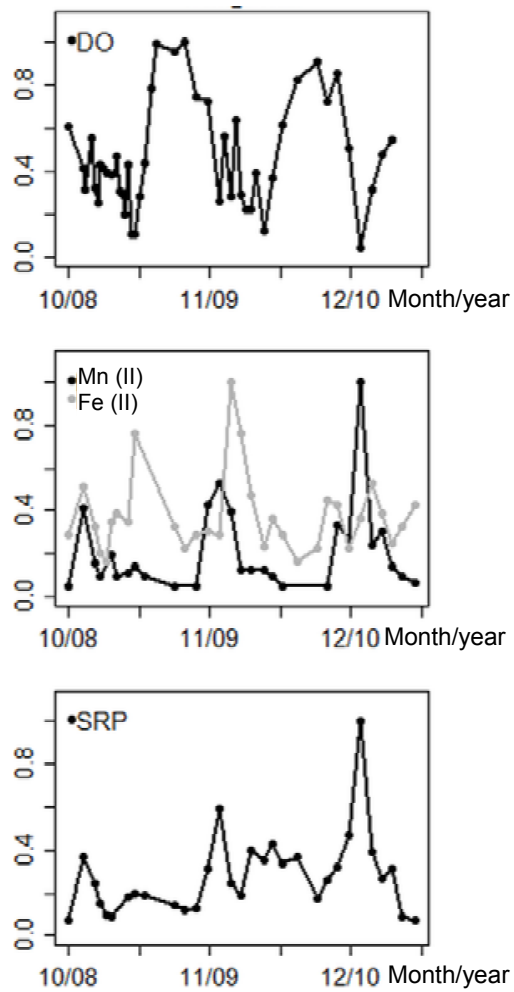

Fig. 4. Normalized temporal curves in deep waters from Garganta station; $\mathrm{DO}=$ dissolved oxygen;

$\mathrm{Mn}$ (II) = manganese (II), Fe (II) = iron (II), SRP = soluble reactive phosphorous; source: own study

In the spring and summer, coincident with thermal stratification, a clear decrease in oxygen is evident in relation to winter values. At the same time, reduced forms of iron and manganese are released into water as a consequence of the reducing action of bacteria [DAVISON, WOOF 1984]. The dissolution of solid forms of iron and manganese oxides is accompanied by phosphate liberation, otherwise adsorbed on such surfaces [ZHOU et al. 2005]. This behaviour was observed for all monitoring sites when the artificial aeration was either absent or intermittent. These results are in good agreement with previous studies into the influence of an anoxic environment on phosphorous release from sediments in the San Roque reservoir [GRANERO et al. 2004]. In addition, BORGINO et al. [2006] studied morphological and chemical composition of sediments from this reservoir as well as phosphate release under laboratory conditions. They demonstrated that $\mathrm{Fe}(\mathrm{OOH})$ and $\mathrm{CaCO}_{3}$ represent principal adsorption sites in this reservoir and release rate of phosphate increased by increasing $\mathrm{pH}$ and temperature. No reference to manganese compounds is made in those works. From Figures 3 and 4 it can be seen that the correlation between the concentrations of bottom phosphate and manganese (II) is higher than the analogous correlation with iron (II) i.e. 0.7 versus 0.2 . These differences could be understood in terms of ferrous sulphide formation in the sediments [DAVISON, WoOF 1984]. It must be mentioned that the presence of $\mathrm{Al}(\mathrm{OH})_{3}$ and irreducible iron (III) minerals can enhance $P$ retention even in anoxic conditions, but such is not the case for Lake San Roque, where $\mathrm{Fe}(\mathrm{OOH})$ and $\mathrm{CaCO}_{3}$ are main adsorbents. It is worth noticing that, despite the fact that thermal stratification inhibits convective mixing between the hypolimnion and the epilimnion, Microcystis species are capable of vertical migration from the surface in order to take phosphate from bottom and then return for blooming [VISSER et al. 1997]. Although short-term decreases in phosphorous releases from sediments can be achieved by preventing sediment anoxia, long-term solutions should involve reductions in external inputs. A recent study carried out in eutrophicated fresh waters from The Netherlands showed an improvement in water quality in the period 1990-2003 and stabilization since 2004 associated with nutrient loading control policies [VAN PUIJENBROEK et al. 2014].

\section{EUTROPHICATION AND THERMAL STRATIFICATION. TEMPORAL ANALYSIS}

\section{Year and season factors}

Figure 5 shows the box plots for the natural logarithm of chlorophyll-a for each season (from October 2008 to June 2011) and also for the corresponding summers of three different years. From Figure 5a it is evident that the chlorophyll median for the summer is statistically different from those of the rest of the year. The same can be observed for spring and winter medians. Inter annual comparison 2009-2011 is shown in Figure 5b. Only summer values were considered, since no significant differences in data were observed in winter months. Chlorophyll values for summers 2009, 2010, and 2011 were statistically different. Data analysis shows that the level of chlorophyll-a was significantly lower in 2010, a rainy year 


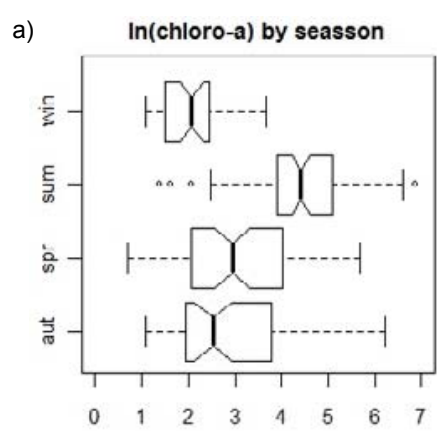

b)

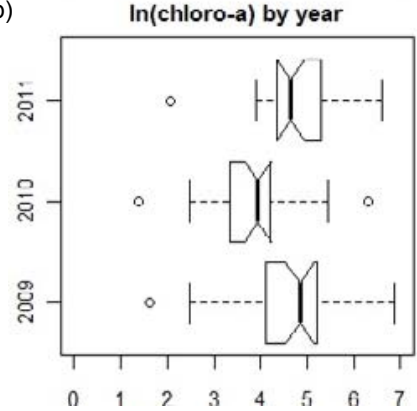

Fig. 5. Box plots of the logarithm of chlorophyll-a concentration including all sites; a) season factor (aut = autumn, $\mathrm{spr}=$ spring, sum $=$ summer, win $=$ winter , b) year factor (only for summer data); source: own study

in relation to 2009 and 2011. ILNICKI [2014] has recently suggested that point sources of $\mathrm{P}$ provide the most significant risk for eutrophication, even in rural areas with high agricultural losses where precipitation and runoff causes a large inter-annual nutrient load variability.

\section{Dependence of the value of chlorophyll- $a$ and other species with sampling time}

It is a well-known fact that many variables either directly or indirectly connected with the photosynthesis process, are dependent on solar irradiation. Thus, their representative values are expected to change through the day. Surprisingly, little information based on field measurements can be found on this topic, i.e. [NIMICK et al. 2011]. Nimick et al. summarized biogeochemical processes that took place in streams over 24 hours and the associated changes in aqueous chemistry. They observed a huge dependence of $\mathrm{pH}$ and oxygen on time. In order to follow these temporal changes, we collected water samples and made in situ measurements in the centre of the San Roque reservoir at intervals of one hour around midday. Figure 6 shows the corresponding values of $\mathrm{pH}$ and chlorophyll-a measured on 23th of May 2011.

There is a high correlation between $\mathrm{pH}$ and chlorophyll-a concentration. This is hardly surprising since both vary synchronously with algal production, which in turn is strongly dependent on temperature and solar irradiation. On this particular day, weather conditions were very good, especially the absence of strong winds, although a variable low cloud cover was observed. The linear regression analysis between chlorophyll-a and $\mathrm{pH}$ gave a regression coefficient $r^{2}$

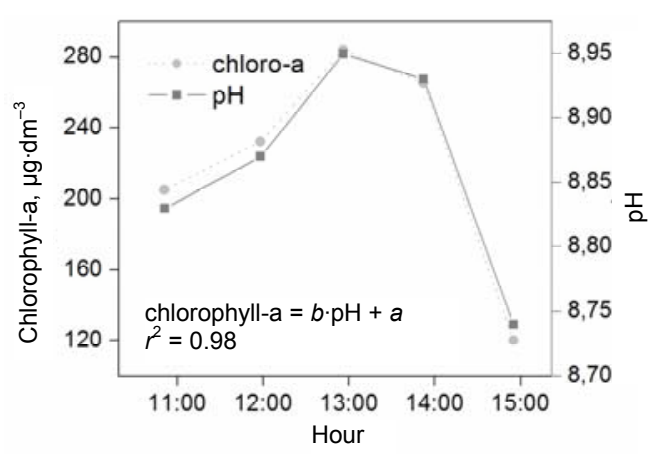

Fig. 6. Chlorophyll-a and $\mathrm{pH}$ as a function of time for an experiment carried out at Centre station on a windless and warm autumn day (23th of May 2011). The inset legend shows a linear regression equation for a chlorophyll-a versus $\mathrm{pH}$ curve, where $a=-6494.4, b=757.6$, and $r^{2}=$ 0.98 ; source: own study

equal to 0.98 . This result is important because it opens up the possibility for designing fast and low cost monitoring protocols based on variables such as $\mathrm{pH}$, and from these, to estimate more complex and costly ones such as chlorophyll-a.

It is very important to notice the big difference between chlorophyll-a at $13 \mathrm{pm}\left(284 \mu \mathrm{g} \cdot \mathrm{dm}^{-3}\right)$ and two hours later, at $15 \mathrm{pm}\left(120 \mu \mathrm{g} \cdot \mathrm{dm}^{-3}\right)$, which can be adscribed to differences in cloud cover, that is to say, in solar light intensity on surface waters. This is consistent with bivariate analysis between the incident radiation and the concentration of chlorophyll-a, as discussed in section "Bivariate analysis". We did not find in the literature similar experiments reported for a lake, since sampling time seems to be considered irrelevant. Nevertheless, it might be taken into consideration when we are interested in the spatial variations of given variables, since samples are not collected simultaneously but in a sequential way, at different sampling times.

\section{EUTROPHICATION AND THERMIC STRATIFICATION. SPATIAL ANALYSIS}

As it was demonstrated in section "Evidences of internal phosphate source's mechanism", thermal stratification in water column influences surface chemical composition due to nutrient release from sediments. In this section spatial analysis was divided into horizontal and vertical behaviour of the variables of interest in order to evaluate thermocline effects.

\section{Vertical profiles of dissolved oxygen and temperature}

Figure 7 presents an example of temperature and dissolved oxygen profiles for a typical summer day measured at SAT 1 station. These curves are representative of a monomictic reservoir in summer. This behaviour was reported for the San Roque reservoir before the diffuser system was implemented [ALEXANDER, IMBERGER 2009; ANTENUCCI et al. 2003; GRANERO et al. 2004], and once it was in operation 


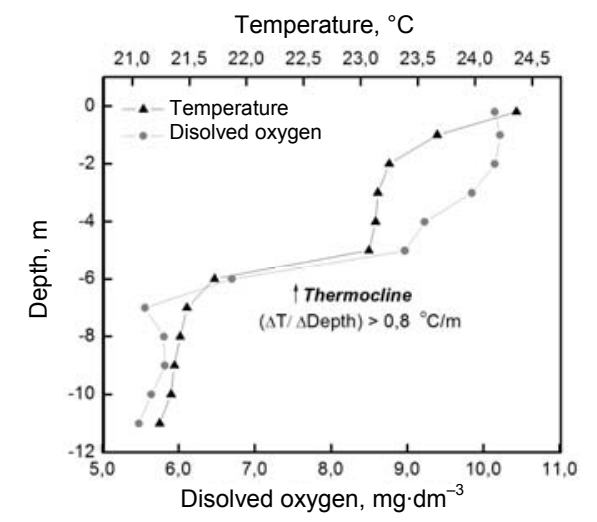

Fig. 7. Temperature and dissolved oxygen profiles measured in situ at SAT 1 station in the summer $\left(4^{\text {th }}\right.$ of December 2008); thermocline is observed at $5 \mathrm{~m}$ depth; source: own study

[FERNANDEZ et al. 2012]. It can be observed that temperature and dissolved oxygen decrease with depth. In addition, marked changes in both curves denote thermocline presence at a depth around five meters. In order to quantify artificial aeration influence on thermocline presence, a frequency study was carried out. A R routine was performed in order to evaluate numeric derivatives of more than 400 profiles of temperature versus depth. A ratio equal to or greater than $0.8^{\circ} \mathrm{C} \cdot \mathrm{m}^{-1}$ was considered indicative of thermocline presence.

Figure 8 presents a histogram of thermal stratification frequencies for all monitoring sites. Bars corresponding to those located in diffuser zones are remarkable shorter (Garganta, Zone A and Zone B). This is the first time an analysis of experimental data is able to certainly demonstrate spatial differences in the San Roque reservoir due to artificial aeration with statistical confidence. Previous studies, which had incorporated numerical modelling, indicated that diffusers efficiency depend on operation modes [FERNANDEZ et al. 2012].

In order to correlate thermal stratification with surface chlorophyll-a concentration a $t$-Student test was carried out to compare means between two groups: stratified and not stratified water column scenes. Mean values of chlorophyll-a concentration in the absence and in the presence of thermocline were 58.9 and $117.0 \mu \mathrm{g} \cdot \mathrm{dm}^{-3}$ respectively. Differences between these values could not be proved, since $t$-Student test assumptions were not satisfied. However, they were satisfied for logarithms of chlorophyll-a distribution. This fact does not make data interpretation more difficult since trophic index TSI is a logarithm function of chlorophyll-a. Figure 8 inset shows box plots for the logarithm of chlorophyll-a concentration where means values of 3.2 and 3.8 were obtained in the absence and in the presence of thermal stratification respectively. A $p$ value for $t$-Student test equal to 0.012 , lower than 0.05 , demonstrated with $95 \%$ confidence level that thermal stratification significantly increases the mean value. It is worth noticing that data analyses were carried out over complete

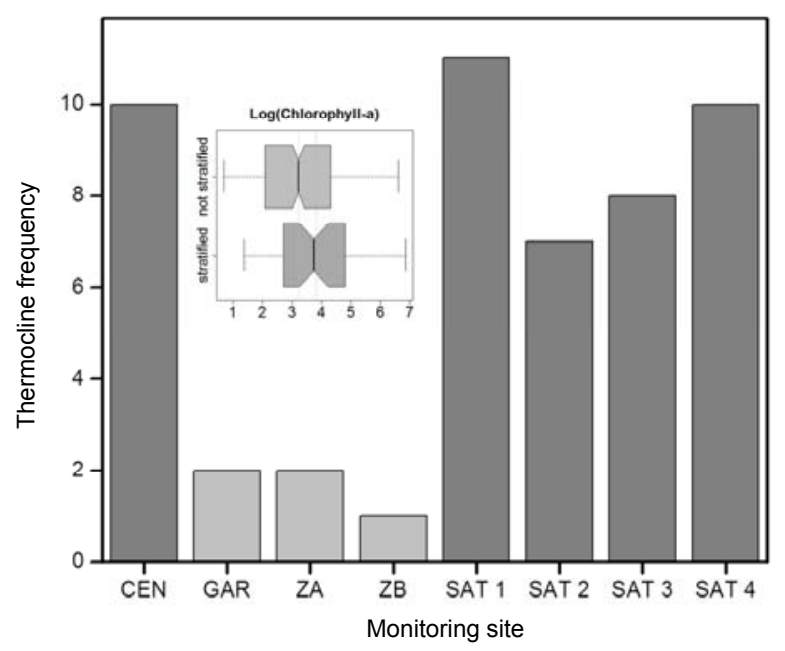

Fig. 8. Frequencies of thermal stratification for all monitoring sites performed over 400 temperature/depth curves. Sites Garganta (GAR), Zone A (ZA) and Zone B (ZB) correspond to points located over the diffusers area. Inset figure corresponds to box plots of the logarithm of surface chlorophyll-a concentration in the presence (dark grey) and absence (light grey) of thermal stratification; source: own elaboration

temporal series were high temporal changes occurs. Analogous analysis was done only for summer and spring data and the tendency did not change. Mean values of chlorophyll-a concentration equal to 88.6 and $128.6 \mu \mathrm{g} \cdot \mathrm{dm}^{-3}$ in the absence and presence of thermal stratification were obtained in such cases. This result demonstrates that seasonal effects themselves do not explain differences in surface chlorophyll-a concentration. The methodology implemented to study vertical profile patterns allowed us, for the first time, to corroborate and state with scientific confidence that artificial aeration systems improved water quality in their influence zone.

\section{Horizontal spatial variation of chlorophyll-a}

The ANOVA test carried out over temporal series of almost all chemical variables did not reveal any spatial differences in the water body. Nevertheless, for some days differences of up to three orders of magnitude for chlorophyll-a concentration could be found between minima $\left(4 \mu \mathrm{g} \cdot \mathrm{dm}^{-3}\right)$ and maxima (900 $\mu \mathrm{g} \cdot \mathrm{dm}^{-3}$ ), evidencing a huge spatial heterogeneity. In marginal statistic approach (ANOVA analysis) temporal changes make spatial patterns not to be detected. For this reason we developed the MENSI index, introduced in section "Materials and methods", which measures the mean temporal behaviour of a variable with respect to the mean value of its spatial domain. This implies that seasonal patterns are eliminated. Number of sites $(N)$ and dates $(M)$ considered in Equation (2) were 8 and 28 respectively. Figure 9 presents MENSI indexes of chlorophyll-a concentration for different sampling points. The horizontal bar corresponds to a MENSI equal to 1 , which indicates that the sampling point behaves like the average of the 


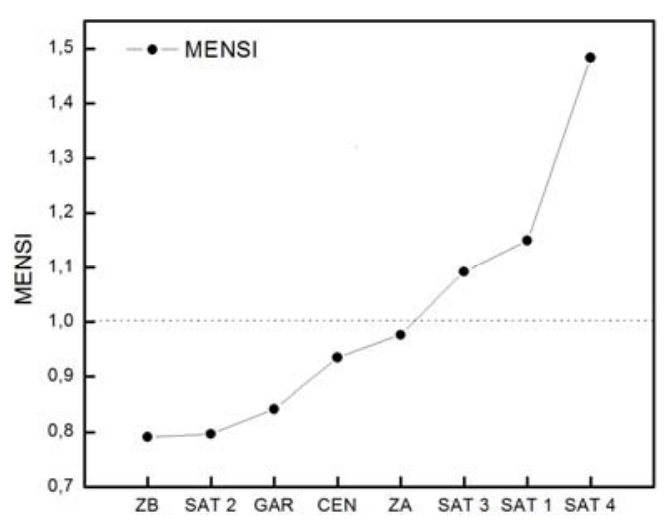

Fig. 9. Mean normalize spatial index (MENSI) values (equation 2) calculated for chlorophyll-a concentration as a function of the monitoring site; $\mathrm{ZB}=\mathrm{Zone} \mathrm{B}, \mathrm{Gar}=$ Garganta, Cen $=$ Centre, ZA = Zone A; source: own study

whole reservoir. Sites situated over diffusers (Garganta, Zone $\mathrm{A}$ and Zone $\mathrm{B}$ ) present MENSI values lower than 1 . The point located at the geometric centre of the reservoir (Centre station) presents a MENSI near 1 . This result agrees well with the analysis performed in section "Marginal statistical analysis", where Centre station resulted to be representative of the mean behaviour of the reservoir. Sites located at Cosquín and San Antonio River entrances (SAT 4 and SAT 1) present the highest MENSI values, 1.2 and 1.5 respectively, indicating that their mean chlorophyll-a concentrations are remarkably higher than the reservoir average. This analysis, performed only over surface data, provides further evidence of spatial differences which can be associated with diffusers and nutrient entries from rivers. Similar patterns were reported for the case of Marne reservoir, in France, by means of Partial Triadic Analysis (statistical approach). In that case, a monitoring station representative of the whole lake was found, and important influences of river entrances on water quality were detected in others [ROLLAND et al. 2009].

\section{PROJECTION TECHNIQUES APPLIED TO TEMPORAL SERIES OF BIOGEOCHEMICAL VARIABLES}

In section "Marginal statistical analysis" it was shown that marginal statistical analysis does not reveal spatial differences between monitoring sites. For further analysis, in this section we present a structure analysis of temporal series of data by means of projection maps built carried out with Temporal Pex software. Aretha et al. proved this to be an innovative and useful tool to find hydrological patterns from the analysis of more than fifty temporal series of river flows in the Paraná region, Brasil [ALENCAR et al. 2008]. Projection techniques is a supporting tool for visual data mining of high dimensional datasets. The goal of projection techniques is to create a twodimensional display from data originally represented in higher dimensional spaces, while striving to layout largely similar points in a way that they can be visu- ally recognized as highly related. These representations allow to employ visual ability to interact and explore the data in search of patterns, trends, or outliers. Point positioning is determined by the multidimensional projection technique, according to a time series dissimilarity measure. Points of same colour represents same class (i.e. chlorophyll-a, temperature, dissolved oxygen, conductivity) as can be seen in Figure 10. Associations between physicochemical variables were explored for one monitoring site, Figure 10 , and spatial patterns were investigated for different sites and variables, Figure 11.

Figure 10 (left) shows a projection map of temperature, dissolved oxygen, surface $\mathrm{pH}$, conductivity, total phosphorus, soluble reactive phosphorus, nitrate and chlorophyll-a, all of them belonging to the Centre monitoring site. In Figure 10 (right) temperature, total phosphate and chlorophyll-a normalized temporal series corresponding to the three highlighted points of the projection map can be seen. All of them were normalized by being divided by their mean value. At left panel It can be observed three nearby points highlighted which correspond to temperature, soluble reactive phosphorus and chlorophyll-a times series. This nearness indicates a marked similarity between times series as can be seen in right panel of Figure 10. This behaviour can easily be understood, since photosynthesis rate is dependent on temperature and availability of a limiting nutrient such as phosphorus. It is worth noticing that this technique is particularly useful for showing relationships between physicochemical variables in a graphic and simple way. This opens up the possibility of performing further studies that involve a larger number of variables.

Times series of four chemical variables, measured in situ, were chosen to explore spatial differences for the eight monitoring sites. A projection map for these 32 temporal series is depicted in Figure 11. As there are more than one times series with same colour (same chemical variable) a number inside the point to identify data set is needed, Figure 11. Five data groups are clearly observed. In principle, it would be expected that points were grouped by colour, since they represent chemical variables. This is the case for some points which forms four sets separated by class: temperature (red), dissolved oxygen (green), conductivity (blue) and pH (cyan). However, the most important feature of Figure 11 is the presence of a fifth set in the centre of the figure for which the spatial distribution is the associating pattern. Thus, points corresponding to SAT 3 and SAT 4 sites are grouped in this central set. This indicates a remarkable spatial influence on the chemical variables measured at these monitoring sites, corresponding to a temporal pattern very different from those of the rest of the reservoir. To a lesser extent, a separation inside each set or colour group is evident. In these cases the series of data corresponding to sites SAT 1 and SAT 2 are located away from the other four points. In Figure 11 (right) a LANDSAT 5-TM image is shown. Blue and red 

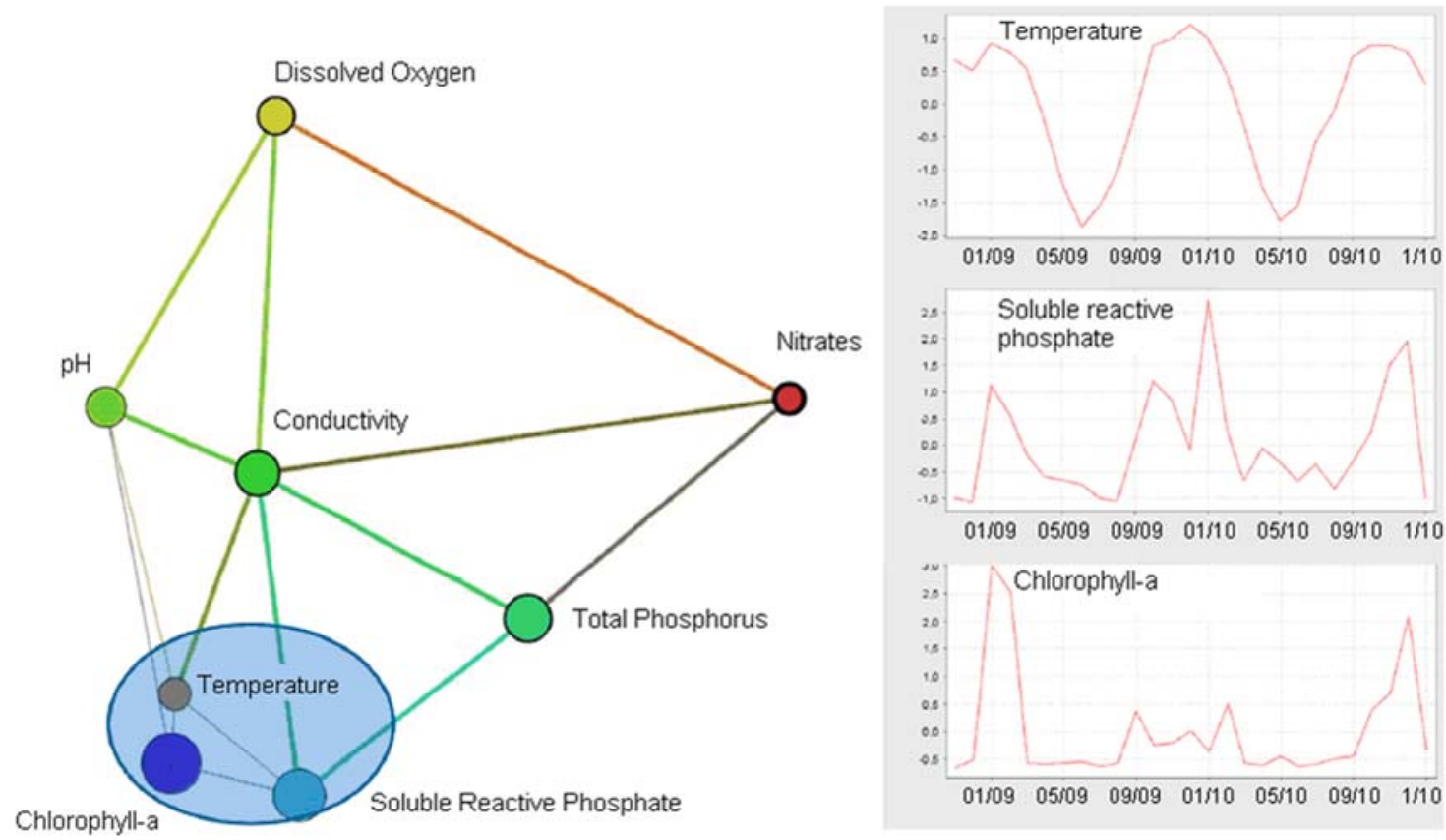

Fig. 10. Temporal series of temperature, oxygen, $\mathrm{pH}$, conductivity, total phosphate, soluble reactive phosphate, nitrate, and chlorophyll-a from Centre station represented in a map projection (left). Temperature, total phosphate and chlorophyll-a normalized temporal series corresponding to the three highlighted points of the projection map (right); source own study
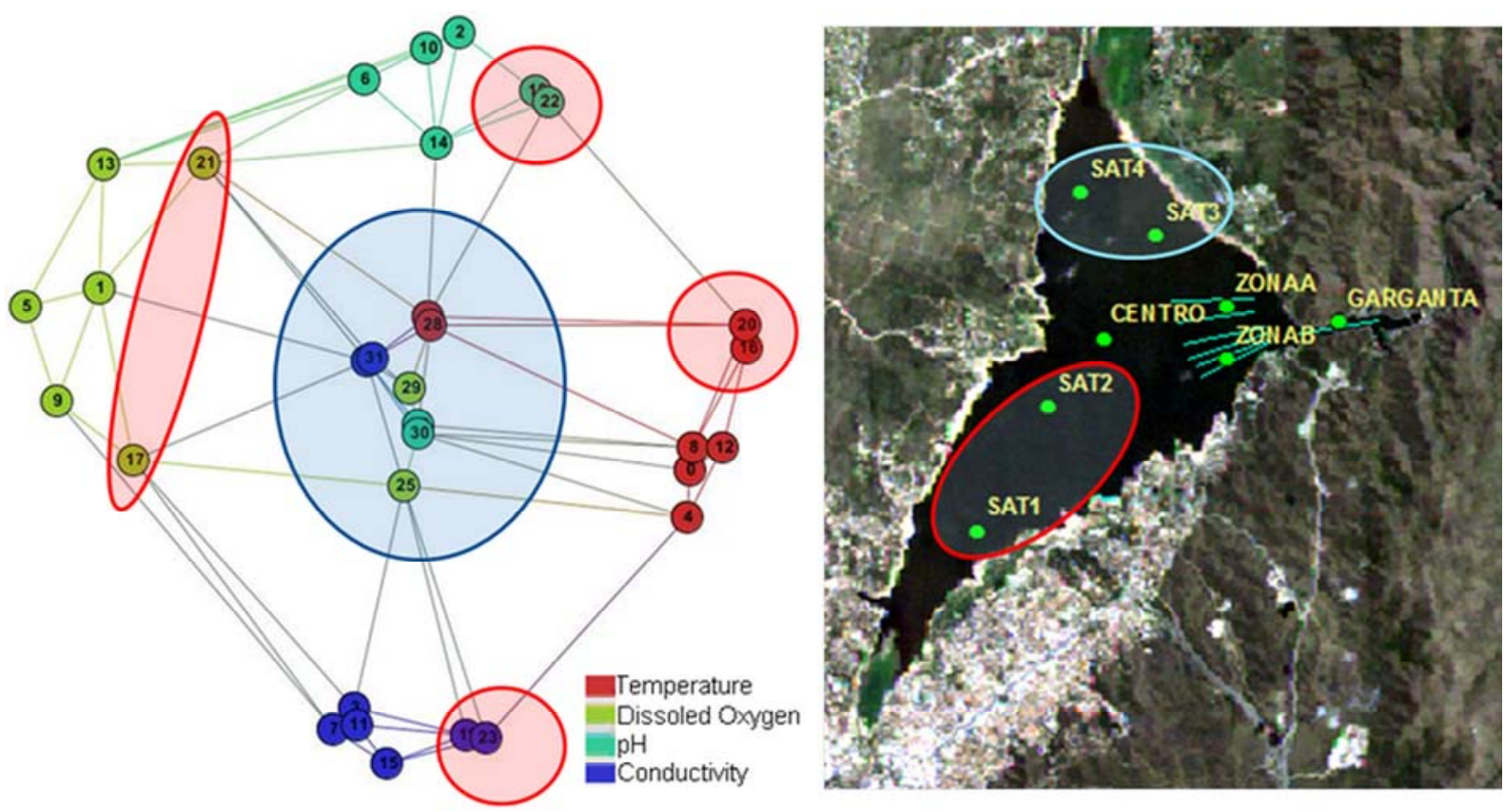

Fig. 11. Map projection of 32 temporal series corresponding to eight monitoring sites and four physicochemical variables. The number inside each circle indicates the series graphed and its colour represents the kind of variable; $0=$ temperature -

Centre; 1 = oxygen - Centre; $2=\mathrm{pH}-$ Centre; $3=$ conductivity - Centre; $4=$ temperature - Garganta; $5=$ oxygen Garganta; $6=\mathrm{pH}-$ Garganta; $7=$ conductivity - Garganta; $8=$ temperature - Zone-A; $9=$ oxygen - Zone A; $10=\mathrm{pH}-\mathrm{Zone}$ A; $11=$ conductivity - Zone A; $12=$ temperature - Zone B; $13=$ oxygen - Zone B; $14=\mathrm{pH}-$ Zone B; $15=$ conductivity Zone B; $16=$ temperature - SAT $1 ; 17=$ oxygen - SAT $1 ; 18=\mathrm{pH}-$ SAT $1 ; 19=$ conductivity - SAT $1 ; 20=$ temperature SAT $2 ; 21=$ oxygen - SAT $2 ; 22=$ pH - SAT $2 ; 23=$ conductivity - SAT $2 ; 24=$ temperature - SAT $3 ; 25=$ oxygen - SAT $3 ; 26=\mathrm{pH}-\mathrm{SAT} 3 ; 267=$ conductivity - SAT $3 ; 28=$ temperature - SAT $4 ; 29=$ oxygen - SAT $4 ; 30=$ pH - SAT $4 ;$ 31 = conductivity - SAT 4 (left). Reservoir zones associated to different patterns of the temporal series are shown with red and blue circles over a LANDSAT 5-TM NASA satellite image (download from CONAE server, National Space Activities Commission) (right); source: own elaboration 
circles are drawn in left and right panels of Figure 11 to associate times series with sampling points on San Roque reservoir. No highlighted data correspond to the monitoring sites Centre, Garganta, Zone A and Zone B. It is easy to observe that the north of the reservoir, near the mouth of the Cosquín River, behaves differently from the rest of the reservoir. This can be interpreted in terms of a greater nutrient availability in the euphotic zone due to water inflow. On the other hand, the southern region also appears as a distinct group, whereas the central and eastern zones make up a third one.

Although this analysis allows visualizing the different groups of variables, it does not provide information on water quality. For this reason, Table 3 summarizes the average values of chlorophyll-a for the temporal series corresponding to the eight monitoring sites and to the three groups found by the Temporal-PEx analysis. It can be observed that the lake centre and the region close to the diffusers have, on average, the lowest chlorophyll-a values, while the highest levels of eutrophication can be seen in the northern area of the reservoir. It is worth noticing that the mean value of Zone A differs from others in its group. This can be understood in terms of water flux coming from the northern region [ALEXANDER, IMBERGER 2009], where chlorophyll-a concentration is higher.

Table 3. Mean chlorophyll-a concentration for the three different zones identified with Temporal-PEx analysis

\begin{tabular}{|c|c|c|c|c|c|c|c|}
\hline \multicolumn{8}{|c|}{ Mean chlorophyll-a concentration, $\mu \mathrm{g} \cdot \mathrm{dm}^{-3}$} \\
\hline \multicolumn{4}{|c|}{ Centre-WEST } & \multicolumn{2}{|c|}{ South } & \multicolumn{2}{|c|}{ North } \\
\hline Ü & 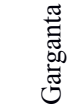 & $\begin{array}{l}\varangle \\
o \\
0 \\
N\end{array}$ & 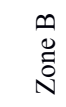 & 悹 & 悹 & $\underbrace{n}_{\text {岁 }}$ & 宏 \\
\hline 69.9 & 53.7 & 81.0 & 46.2 & 77.9 & 51.3 & 85.7 & 139.6 \\
\hline \multicolumn{4}{|c|}{62.7} & \multicolumn{2}{|c|}{64.6} & \multicolumn{2}{|c|}{112.0} \\
\hline
\end{tabular}

Source: own study.

The analysis performed with the Temporal-PEx program gives strong evidence of the spatial difference existing in the Roque reservoir, which was not possible to demonstrate by marginal statistical methods. It is worth mentioning that projection analysis is a powerful tool to emphasize the positive effects of diffusers on water quality. The incidence of rivers was also detected by this technique.

\section{CONCLUSIONS}

1. The artificial aeration system installed in the San Roque reservoir in 2008 had favourable effects on water quality in its area of influence.

2. ANOVA analysis proved to be an unsuitable tool for assessing differences in biogeochemical variables according to the monitoring site. This was probably due to the large temporal dispersion of data.
This conclusion can be extrapolated to other water bodies of similar characteristics.

3. A structure analysis of temporal series allowed, for the first time, to characterize three different zones in the reservoir, as well as to visualize relationships between physicochemical variables.

4. The MENSI index allowed to determine that the average chlorophyill-a values of those sites located near diffusers is lower than the average value for the lake on each date.

5. An analysis of field measurements confirmed, with 95 percent confidence, that physicochemical variables in the centre of the reservoir are representative of the yearly average reservoir behaviour. Accordingly, the Centre zone can be used as a reference point for the temporal evolution of the reservoir.

6. In windless days it is possible to model the chlorophyll-a concentration from $\mathrm{pH}$ measurements with 98 percent certainty. Note that $\mathrm{pH}$ monitoring involves lower sampling time, low cost of analysis and easy automation.

7. The mechanism for phosphorus release from sediments was confirmed. As expected, a decrease in dissolved oxygen was observed, which was followed by an increase in the concentrations of Fe (II) and Mn (II) species in the hypolimnion.

8. An in-situ experiment showed that monitoring time strongly affects chlorophyll-a concentration since changes greater than $50 \%$ in 2 hours were registered. However, though significant, there is a small positive relationship between chlorophyll-a and incident radiation when three year data are considered. This poor correlation might be related with the influences of other limiting factors of algae growth as wind, nutrients concentration and temperature.

9. In relation to phytoplankton variables, the group of cyanophytes is the largest contributor, on average, to the abundance of species in algal blooms.

10. It was verified that this reservoir behaves as a eutrophic water body, being hypertrophic in the summer and mesotrophic in the winter. As expected for this type of reservoirs, the average values of chlorophyll-a are significantly higher in the summer than in the winter.

11. The working platform $\mathrm{R}$ greatly facilitated data mining, i.e. the statistical analysis and numerical modelling of scientific and operational variables of interest based on the successful management and analysis of large amounts of data.

\section{Acknowledgements}

This work was supported by the Secretary of Water Resources and Coordination of the province of Córdoba ( $\mathrm{Sp}$. Secretaría de Recursos Hídricos de la provincia de Córdoba). A. Ferral thanks National Space Activities Commission CONAE (Sp. Comisión Nacional de Actividades Espaciales) for the fellowship granted. Special thanks to Trad. K. Placencia for language revision and to Lic. L. Colladon from National Institute of Water INA (Sp. Instituto Nacional del Agua) for providing radiation data. 


\section{REFERENCES}

AJeagah G.A., Abanda W.V.B., Nkeng G.E. 2017. An application of a water assessment and simulation model in the remediation of the eutrophication capacity of a tropical water system: Case study the Lake Obili in Yaounde (Cameroon). Journal of Water and Land Development. No. 33 p. 11-22. DOI 10.1515/jwld-20170014.

Alencar A.B., Paulovich F.V., Minghim R., Filho M., OliveIRA M. 2008. Similarity-based visualization of time series collections: An application to analysis of streamflows. Information Visualisation. 08.04.2008IV '08. 12th International Conference. London, UK. 9-11 July 2008.

ALEXANDER R., IMBERgER J. 2009. Spatial distribution of motile phytoplankton in a stratified reservoir: The physical controls on patch formation. Journal of Plankton Research. Vol. 31. Iss. 1 p. 101-118.

AmÉ M.V., Del Pilar Díaz M., Wunderlin D.A. 2003. Occurrence of toxic cyanobacterial blooms in San Roque reservoir (Córdoba, Argentina): A field and chemometric study. Environmental Toxicology. Vol. 18. Iss. 3 p. 192-201.

ANTENUCCI J.P., AlEXANDER R., Romero J.R., IMBERGer J. 2003. Management strategies for a eutrophic water supply reservoir - San Roque, Argentina. Water Science and Technology. Vol. 47. Iss. 7-8 p. 149-155.

Borgnino L., Avena M., De Pauli C. 2006. Surface properties of sediments from two Argentinean reservoirs and the rate of phosphate release. Water Research. Vol. 40. Iss. 14 p. 2659-2666.

CARLSON R.E. 1977. A trophic state index for lakes. Limnology and Oceanography. Vol. 22. Iss. 2 p. 361-369.

DAVISON W., WoOF C. 1984. A study of the cycling of manganese and other elements in a seasonally anoxic lake, Rostherne Mere, UK. Water Research. Vol. 18. Iss. 6 p. 727-734.

Douglas G.B., Hamilton D.P., RobB M.S., Pan G., Spears B.M., LuRLING M. 2016. Guiding principles for the development and application of solid-phase phosphorus adsorbents for freshwater ecosystems. Aquatic Ecology. Vol. 50. Iss. 3 p. $385-405$.

Eaton A.D., Clesceri L.S., Greenberg A.E. (eds.) 2005. Standard methods for the examination of water and wastewater. $21^{\text {st }}$ ed. Washington, DC. American Public Health Association, American Water Works Association, Water Environment Federation. ISBN 9780875530475 pp. 1200.

Fernandez R., Bonansea M., Cosavella A., Monarde F., FERREYRA M., BRESCIANO J. 2012. Effects of bubbling operations on a thermally stratified reservoir: Implications for water quality amelioration. Water Science and Technology. Vol. 66. Iss. 12 p. 2722-2730.

FRIENDLY M. 2002. Corrgrams: Exploratory displays for correlation matrices. The American Statistician. Vol. 56. Iss. 4 p. $316-324$.

GÄCHTER R., WEHRLi B. 1998. Ten years of artificial mixing and oxygenation: no effect on the internal phosphorus loading of two eutrophic lakes. Environmental Science and Technology. Vol. 32. Iss. 23 p. 3659-3665.

Granero M., Bustamante A., López F., Ruiz M. 2004. Hipolimnion water quality and its relationship to internal $\mathrm{P}$ loading in an eutrophicated water body: San Roque reservoir (Córdoba, Argentina). Journal of Hydraulic Research. Vol. 42. Iss. 3 p. 310-315.
GromieC M., Gromiec T. 2010. Controlling of eutrophication in aquatic environments. Journal of Water and Land Development. Vol. 14 p. 29-35.

Hamilton D.P., Salmaso N., Paerl H.W. 2016. Mitigating harmful cyanobacterial blooms: strategies for control of nitrogen and phosphorus loads. Aquatic Ecology. Vol. 50. Iss. 3 p. 351-366.

ILNICKI P. 2014. Emissions of nitrogen and phosphorus into rivers from agricultural land - selected controversial issues. Journal of Water and Land Development. No. 23 p. 31-40. DOI 10.1515/jwld-2014-0027.

ImTEAZ M.A., AsaedA T. 2000. Artificial mixing of lake water by bubble plume and effects of bubbling operations on algal bloom. Water Research. Vol. 34. Iss. 6 p. 1919-1929.

LAWSON R., ANDERSON M.A. 2007. Stratification and mixing in Lake Elsinore, California: An assessment of axial flow pumps for improving water quality in a shallow eutrophic lake. Water Research. Vol. 41. Iss. 19 p. 4457-4467.

LOVLEY D.R., PHILLIPS E.J. 1988. Novel mode of microbial energy metabolism: organic carbon oxidation coupled to dissimilatory reduction of iron or manganese. Applied and Environmental Microbiology. Vol. 54. Iss. 6 p. $1472-1480$.

MoOre S.K., Trainer V.L., Mantua N.J., Parker M.S., LAWS E.A., BACKER L.C., FLEMING L.E. 2008. Impacts of climate variability and future climate change on harmful algal blooms and human health. Environmental Health. Vol. 7. Iss. 2 S4.

MORTIMER C.H. 1942. The exchange of dissolved substances between mud and water in lakes. The Journal of Ecology. Vol. 30. No. 1 p. 147-201.

Nicklisch A., Shatwell T., KöHLER J. 2008. Analysis and modelling of the interactive effects of temperature and light on phytoplankton growth and relevance for the spring bloom. Journal of Plankton Research. Vol. 30. Iss. 1 p. $75-91$.

Nimick D.A., GAmmons C.H., PARKer S.R. 2011. Diel biogeochemical processes and their effect on the aqueous chemistry of streams: A review. Chemical Geology. Vol. 283. Iss. 1 p. 3-17.

PAerl H.W., Paul V.J. 2012. Climate change: links to global expansion of harmful cyanobacteria. Water Research. Vol. 46. Iss. 5 p. 1349-1363.

PARINET J., RODRIGUEZ M.J., SÉRODES J. 2010. Influence of water quality on the presence of off-flavour compounds (geosmin and 2-methylisoborneol). Water Research. Vol. 44. Iss. 20 p. 5847-5856.

R Development Core Team 2013. R: A language and environment for statistical computing. Vienna, Austria. R Foundation for Statistical Computing.

Rolland A., Bertrand F., Maumy M., JacQuet S. 2009. Assessing phytoplankton structure and spatio-temporal dynamics in a freshwater ecosystem using a powerful multiway statistical analysis. Water Research. Vol. 43. Iss. 13 p. $3155-3168$.

Ruiz M., Galanti L., Ruibal A.L., Rodriguez M.I., WunderLin D.A., AMÉ M.V. 2013. First report of microcystins and anatoxin-a co-occurrence in San Roque reservoir (Córdoba, Argentina). Water, Air, and Soil Pollution. Vol. 224. Iss. 6 p. 1-17.

SteInMAN A.D., Isely E.S., THOMPSON K. 2015. Stormwater runoff to an impaired lake: impacts and solutions. Environmental Monitoring and Assessment. Vol. 187. Iss. 9, 549 pp. 14. 
Stitz L., KinNEAR S., FABBRo L. 2013. A role for aeration and intake depth in managing toxic Cylindrospermopsis: A comparison between off stream and riverine environments in the Fitzroy Basin, Australia. Lakes and Reservoirs: Research and Management. Vol. 18. Iss. 2 p. 179-196.

Stumm W., Morgan J.J. 2012. Aquatic chemistry: chemical equilibria and rates in natural waters. Vol. 126. John Wiley and Sons. ISBN 9781118591482 pp. 1040.

Van Puijenbroek P., Cleij P., Visser H. 2014. Aggregated indices for trends in eutrophication of different types of fresh water in the Netherlands. Ecological Indicators. Vol. 36 p. 456-462.
VisSer P.M., PAsSARge J., Mur L.R. 1997. Modelling vertical migration of the cyanobacterium Microcystis. Hydrobiologia. Vol. 349. Iss. 1-3 p. 99-109.

Vonlanthen P., BitTner D., HudSON A., Young K., MÜLLER R., LundSGAARD-HANSEN B., Roy D., Di Piazza S., LARGiader C.R., SEEHAUSEN O. 2012. Eutrophication causes speciation reversal in whitefish adaptive radiations. Nature. Vol. 482. Iss. 7385 p. 357-362.

Zhou A., TANG H., WANG D. 2005. Phosphorus adsorption on natural sediments: Modeling and effects of $\mathrm{pH}$ and sediment composition. Water Research. Vol. 39. Iss. 7 p. $1245-1254$.

\section{Anabella FERRAL, Velia SOLIS, Alejandro FRERY, Alejandro ORUETA, Ines BERNASCONI, Javier BRESCIANO, Carlos M. SCAVUZZO}

\section{Przestrzenne i czasowe zmiany jakości wody w eutroficznym jeziorze ze sztucznym napowietrzaniem}

\section{STRESZCZENIE}

W pracy przedstawiono oryginalne wyniki dotyczące zmian jakości wody w eutroficznym zbiorniku wodnym związanych z zainstalowanym tam systemem sztucznego napowietrzania. Od października 2008 do czerwca 2011 r. dokonywano co miesiąc in situ i w laboratorium 61 pomiarów parametrów biogeochemicznych aby ocenić czasowe i przestrzenne zmiany w zbiorniku San Roque (Argentyna). Testy $t$-Studenta prowadzone dla całego okresu badawczego wykazały z 95-procentowym poziomem ufności, że stanowisko monitoringu zlokalizowane w centrum zbiornika wodnego jest reprezentatywne dla właściwości chemicznych całego zbiornika. Stratyfikację termiczną obserwowano latem we wszystkich stanowiskach badawczych, ale częstość wystąpień tych epizodów była znacząco mniejsza w strefie napowietrzania. Średnie stężenie chlorofilu a wynosiło 58,9 $\mu \mathrm{g} \cdot \mathrm{dm}^{-3}$ i $117,0 \mu \mathrm{g} \cdot \mathrm{dm}^{-3}$ odpowiednio w warunkach braku i w warunkach występowaniu termokliny. Różnica wg testu $t$-Studenta była statystycznie istotna, gdy $p<0,001$. Stwierdzono uwalnianie fosforanów $\mathrm{z}$ osadów w warunkach deficytu tlenowego. Jednoczynnikowa analiza ANOVA nie wykazała istotnego zróżnicowania przestrzennego żadnego z mierzonych parametrów. Utworzono średni znormalizowany indeks przestrzenny (MENSI) do porównania danych cechujących się dużą zmiennością czasową pochodzących z różnych regionów. Indeks okazał się użyteczny do ilościowego przedstawienia różnic przestrzennych. Przeprowadzono analizę struktury szeregów czasowych, aby przeanalizować powiązanie cech chemicznych ze zmiennością przestrzenną. Wyodrębniono trzy chemicznie odmienne strefy zbiornika. Badania wykazały, że analiza przestrzenna za pomocą statystyki jednoczynnikowej może nie być odpowiednią metodą w warunkach dużej zmienności czasowej. W takim przypadku należy rozważyć analizę struktury czasowej.

Słowa kluczowe: analiza statystyczna, eutrofizacja, fosforany, jakość wody, stratyfikacja termiczna, szeregi czasowe, techniki projekcji 